\title{
Phytoplasma infection status survey in plum psyllid (Cacopsylla pruni) population
}

\author{
${ }^{2}$ Dominika Bodnár $-{ }^{1}$ Brigitta Szalai $-{ }^{1}$ Gábor Tarcali $-{ }^{2}$ Orsolya Viczián $-{ }^{2}$ Emese Mergenthaler \\ ${ }^{1}$ Department of Plant Protection, Faculty of Agriculture, University of Debrecen, \\ 4032 Debrecen, Böszörményi út 138. \\ ${ }^{2}$ Centre for Agricultural Research, Hungarian Academy of Science, Plant Protection Institute, \\ 1022 Budapest, Hermann Ottó út 15. \\ bodnrominika.dominika5@gmail.com
}

\begin{abstract}
SUMMARY
European Stone Fruit Yellows (ESFY) phytoplasma disease causes an increasing amount of damage. This is especially true to the Gönci growing region. The insect vector of the disease, which has been shown to have a vector role during transmission experiments, is the plum psyllid (Cacopsylla pruni). In 2018, during the swarming period of plum psyllid, in 3 different settlements (Boldogköváralja, Nagyvárad and Bekecs) 265 psyllidswere collected, from which 165 were plum psyllid. Molecular biology studies showed 106 individuals infected with phytoplasma, of which 20 were males and 86 were females.
\end{abstract}

Keywords: plum psyllid, infected phytoplasma

\section{INTRODUCTION}

European Stone Fruit Yellows (ESFY) phytoplasma disease causes more and more problems in stone fruit orchards, especially in apricot plantations. The importance of the damage caused by the pathogen (' $\mathrm{Ca}$. Phytoplasma prunorum') is priority in the Gönci apricot growing region since this growing region gives near the $40 \%$ of the national apricot yield. Within the Gönci growing region there are two settlements are highly important since the $80 \%$ of the apricot orchards of this growing region are inside the administrative border of Boldogkőváralja and Gönc. 55-70\% of infection in Bekecs and $77 \%$ of infection in Boldogkőváralja were determined in apricot orhards in 2009 (Tarcali et al., 2010).

So far the only known vector, of which vector role was proved by transmissional experiments, is the plum psyllid (Cacopsylla pruni). Their feeding habit is oligophagous, related to Prunus species (Ripka, 2010). Their occurrence is more frequent in warmer regions. However, in Hungary the species have not become expansively spread, their occurrence was reported from Vas, Somogy, Pest and Borsod-Abaúj-Zemplén counties. Though there are efforts to cure the disease: treatment with penicillin derivatives (Kuroli, 1970), treatment with tetracyclin derivatives (Davis-Clark, 1994; Douglas, 1993), water-bath treatment (SalazarJavashinge, 2001), in vitro shoot tip culture (FaccioliColalongo, 2002), callus culture (Möllers-Sarkar, 1989), examintations of interaction between phytoplasma strains of different virulence and its impact on the development of cross protection (Tibenszkyné, 2015), but for now these methods have no satisfactory results in practice. Therefore, emphasis should be placed on the use of aseptic propagation material, prevention and to prevent the spreading of the disease. One important tool of these is the protecting against the vector.

The aim of our research is to survey the infection rate of the vector, in the case of both the nyphms and the imagos on as many areas as possible. Additionally, we also want to check exactly which strains of pathogen is carried by the infected individuals, and how the vectors use the areas. In our opinion, the deeper knowledge of these is very important for the development of a suitable defense-method. For the sake of the cause, we started an overall, multi-faceted study. Within the scope of this article, only an examination of the infection rate of collected plum psyllids is presented as the molecular biology studies related to the rest of the experiment is still in progress.

\section{MATERIALS AND METHODS}

The swarming time of plum psyllids (Cacopsylla pruni) was in the period between 2018, April 13. and May 10. During this time vectors were collected in three different settlements (Nagyvárad, Bekecs and Boldogkőváralja). Vectors were captured by aspirator and placed in small plastic tubes which contained $70 \%$ medical alcohol, these tubes were kept in a refrigerator until the laboratory tests. Collected individuals were identified under laboratory conditions with the help of an lightmycroscope, each one get a laboratory code, there were also recorded if any interesting thing were seen on them (eg. darker or lighter colors than speciesspecific, or smaller than the average). We extraxt the DNA of each individual one by one, but in the case of PCR, in some cases we worked with groups, and after we found that the bulk gave positive results to the infection, we also tested them individually, that we can found the concret individual from the bulk which gave positive result. In the case of the individuals that were captured in Bekecs and Nagyvárad, the psyllids were PCR tested by individually, but in the case of which were captured in Boldogkőváralja, for the first step we made groups from the DNA 5 individuals in each groups, if the group proved to be positive, the contained individuals' DNA were retested one by one from the group during PCR to found the exact infected individual. This early step was necessary because of the huge number of individuals. 
DNA extraction was performed by the general extraction method used for DNA extraction of vetors:

$\begin{array}{lllll}\text { 1. } 200 \mu \mathrm{l} & \text { (or } 500 \mu \mathrm{l}) & \mathrm{CTAB}\end{array}$ (cetyltrimethylammounium bromide) buffer was preheated to $60^{\circ} \mathrm{C}$.

2. Mortars were soaked in $5 \%$ hydrochloric acid for 20 minutes and then rinsed with distilled water for sterilization and held on ice.

3. The insect was homogenized by liquid nitrogen in the sterilized braying mortar, then washed with the prepared buffer into centrifuge tube and incubated for 30 minutes in a $60^{\circ} \mathrm{C}$ water bath.

4. After the water bath, it was centrifugated at $12000 \mathrm{rpm}$ for 3 (or 1) minutes at room temperature. Subsequently, the supernatant mixture $(500 \mu \mathrm{l})$ was aspirated and transferred to clean Eppendorf tube. To this a unit $(500 \mu \mathrm{l})$ chloroform: isoamyl alcohol $(24: 1 \mathrm{v} / \mathrm{v})$ solution was added.

5. After 3 minutes of gentle shaking, the mixture was centrifugated at 8000 (or 12000 ) rpm for 8 minutes at room temperature. (At this stage it is important not to brake when the centrifuge is stopped to prevent mixing).

6. Supernatant was transferred to clean Eppendorf tube and a unit of isopropanol $\left(-20^{\circ} \mathrm{C}\right)$ was added. After a few seconds shaking it was centrifugated at 13000 (or 12500 ) rpm for 20 minutes at $4^{\circ} \mathrm{C}$.

7. Arisen supernatant was poured off and $300 \mu \mathrm{l}$ of $70 \%$ ethanol $\left(-20^{\circ} \mathrm{C}\right)$ was added to the pellet and after a few minutes shaking it was centrifugated at 12500 (or 10000 ) rpm for 10 minutes at $4^{\circ} \mathrm{C}$.

8. Arisen supernatant was poured off and the resulted DNA pellet was dried under vacuum or at room temperature. Ethanol free, dried pellet (no scent) was dissolved in 50 (or 100) $\mu$ l of TE buffer (or distilled water) and stored at $4{ }^{\circ} \mathrm{C}$ (if tested in the same day) or $-20^{\circ} \mathrm{C}$ (if stored in a longer time).

Universal primer pairs were used for the infection test (R16F2n/R16R2 for the first PCR and PCR FU5/RU3 for the nested PCR).

Table 1

PCR program parameters

\begin{tabular}{ccc}
\hline & PCR & nested PCR \\
\hline 1. step & $94{ }^{\circ} \mathrm{C}-1$ minutes & $95^{\circ} \mathrm{C}-3$ minutes \\
2. step & $94^{\circ} \mathrm{C}-1$ minutes & $95^{\circ} \mathrm{C}-1$ minutes \\
3. step & $55^{\circ} \mathrm{C}-1: 15$ minutes & $55^{\circ} \mathrm{C}-1$ minutes \\
4. step & $72^{\circ} \mathrm{C}-2$ minutes & $72^{\circ} \mathrm{C}-1$ minutes \\
cicle number & 35 & 34 \\
(2.-4. steps) & & \\
5. step & $72^{\circ} \mathrm{C}-10$ minutes & $72^{\circ} \mathrm{C}-5$ minutes \\
6. step & $12^{\circ} \mathrm{C}-\infty$ & $10^{\circ} \mathrm{C}-\infty$ \\
\hline
\end{tabular}

PCR products were run in $1 \%$ agarose gel containing GelRed for 25 minutes at 100 volts and the pattern was exposed under UV light. As marker size ladder Fast Ruler $^{\mathrm{TM}}$ Middle Range DNA Ladder was used.

\section{RESULTS AND DISCUSSION}

In 2018, during the swarming period, 265 psyllids were collected, from which 165 were plum psyllid (Cacopsylla pruni). 18 young adults (freshly hatched) and 14 nymphs were also collected. From the collected plum psyllids 106 individuals were found to be infected with phytoplasma, identified by molecular biological studies with universal primers. From this 106 individuals 20 were males and 86 were females (Figure 1).

Figure 1: Some of the collected individuals on microscopic picture

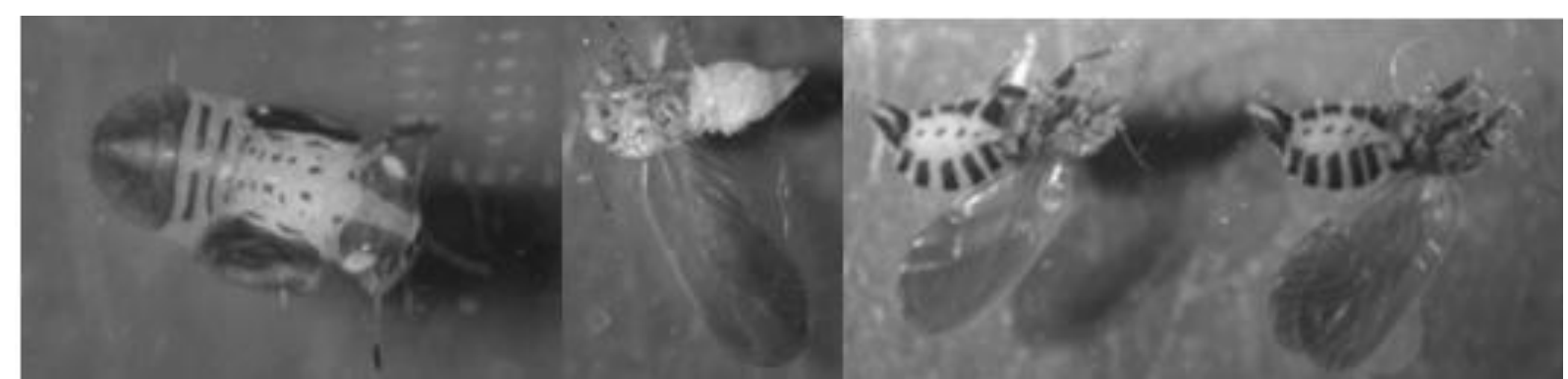

Notice: nymph (to the left); young female imago (in the middle); and also females with lighter and darker wing coloure (to the right)

Eight of the young adults, and eight of the nymphs gave positive results to phytoplasma infection.

The number of plum psyllids collected from the areas of Bekecs were 14 individuals, of which 11 were females and 3 were males. All the males of the collected plum psyllids were found on apricot and were phytoplasma infected. Out of the females, 4 were infected with phytoplasma, which were also collected from apricot trees (Figure 2). In the case of collected plum psyllids from Bekecs $36.6 \%$ of the collected female individuals, and $100 \%$ of the male individuals were infected.

In the areas of Oradea, only one female Cacopsylla pruni was collected, which was proven to be phytoplasma infected. In these areas, it seems valuable to further examine the presence of the vector and the rate of their infection later. 
In the areas of Boldogkőváralja, 150 plum psyllids, and also 18 young adults and 14 nymphs were collected. Out of the imagos 98 individuals (from which 81 females and 17 males), 8 of the young imagos and also 8 of the nymphs were phytoplasma infected (Figure 3).

Figure 2: Phytoplasmal infection of the collected individuals of Bekecs

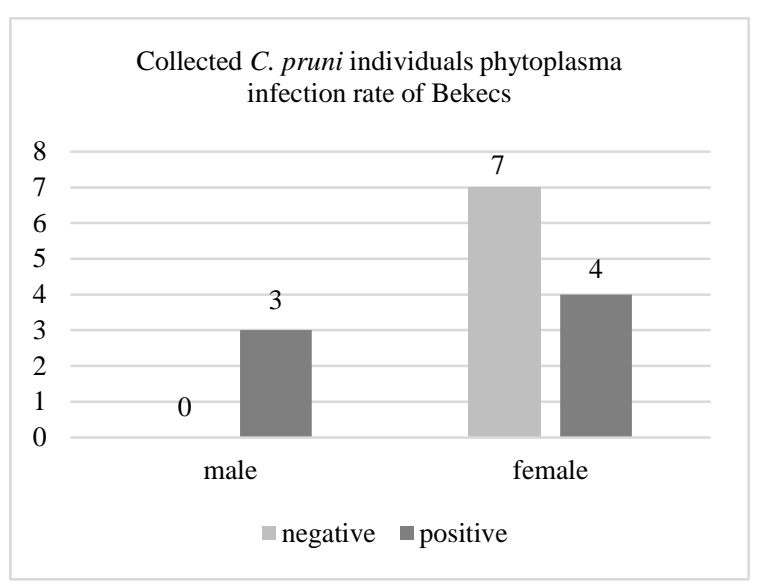

Figure 3: Phytoplasmal infection of the collected individuals of Boldokőváralja

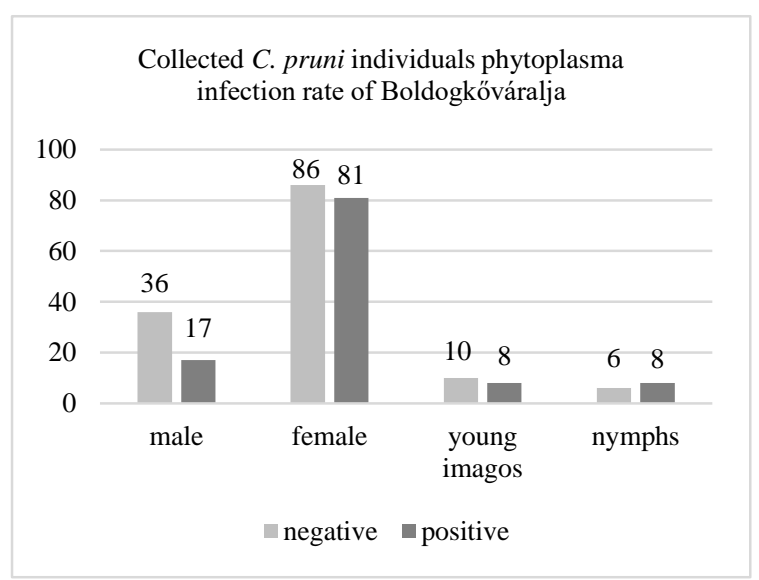

From the plum psyllids collected in Boldogkőváralja $48.50 \%$ of the females and $32.07 \%$ of the males were phytoplasma infected. Additionally, in the case of nypmhs $57.14 \%$ and in the case of young adults $44.44 \%$ were phytoplasma infected from the collected individuals.

\section{CONCLUSION}

Since Cacopsylla pruni's vector role is known in the case of 'Candidatus Phytoplasma prunorum' phytoplasma and in earlier study (Bodnár et al., 2016), we proved the presence of this pathogen on the same areas, the infection of the tested individuals presumable caused by this pathogen.

The high rate of infection in populations in the area explains both the cases of Bekecs and Boldogkőváralja for the rapid and explosive spread of apricot phytoplasmic disease.

The range of phytoplasma infected reimmigrant $C$. pruni was $15 \%$ in France in the highest range, but it was $3 \%$ only in generally (Yvon et al., 2004). The infection range is higher in Turkey with its 23\% (Serçe et al., 2011). The infection range in Hungary, uniformly was about $15 \%$ (in males and females) and somewhat higher $16 \%$ in nypmhs (Mergenthaler at al., 2017). In comparison with these infection ranges, the ranges that were found in this study were much higher.

Based on the results of my parallel study (see: Status survey of apricot plantations for ESFY and its vector in the Gönci growing region), the high infection rate of the plum psyllid population is not always attributable exclusively to the high, rapidly spreading infection in the plantation. It is important, therefore, to examine all factors relevant to a particular plantation that may be involved in the pathogens entering or rapidly spreading in order to establish a suitable defense method for preventing the spread of the disease.

\section{REFERENCES}

Bodnár, D.-Mergenthaler, E.-Viczián, O.-Tarcali, G. (2016): A csonthéjasok európai sárgasága (European Stone Fruit Yellows, ESFY) fitoplazma vektorának, a szilva levélbolhának (Cacopsylla pruni Scopoli) vizsgálata Boldogkőváralja környékén; Agrártudományi Közlemények, 71: 5-11

Davis, D. L.-Clark, M. F. (1994): Maintenance of mycoplasma-like organisms occuring in Pyrus species by mycropropagation and their elimination by tetracycline therapy, Plant Pathology, 43: 819-823

Douglas, S. M. (1993): Cytology, histology and histochemistry of MLO infection in tree fruits. (pp. 253-279) In: A. R. Biggs (ed): Handbook of Cytology, Histology and Histochemistry of Fruit Tree Diseases. CRC Press Florida
Faccioli, G.-Colalongo, C. (2002): Eradication of potato virus Y and potato leafroll virus by chemotherapy of infected potato stem cuttings, Phytopathol., Mediterr., 41: 76-78

Kiss, E.,-Mergenthaler, E.-Kiss, B.-Viczián, O. (2015): A csonthéjasok európai sárgulása (ESFY) magyarországi terjedésének hátterében álló okok. In: Horváth J., Haltrich A., Molnár J. (szerk.) 61. Növényvédelmi Tudományos Napok, Budapest, 2015. február 17-18., 60 p.

Kuroli, G. (1970): Antibiotikumos védekezési kísérletek eredményei a sztolburbetegséggel fertőzött paradicsomnövényeken, A növényvéd. Korsz. 4: 19-30

Mergenthaler, E.-Viczián, O.-Kiss, B.-Kiss, E. (2017): Survey on the occurrence and infection atatus of Cacopsylla pruni, vector 
of European Stone Fruit Yellows in Hungary; Bulletin of Insectology; 70(2): 171-176

Möllers, C.- Sarkar, S. (1989): Regeneration of healthy plants from Catharanthus roseus infected with mycoplasma-like organisms through cellus culture, Plant. Sci. 60 (1): 83

Ripka, G. (2010): Levélbolhák, Agroinform kiadó, Budapest, ISBN: 978-963-502-913-6, $104 \mathrm{p}$.

Salazar, L.-Javasinghe, U. (2001): Diseases caused by phytoplasma in potato. International Potato Center (CIP). Techniques in Plant Virology. Training Manual. Lima, Peru

Serçe, Ç. U.-Yvon, M.-Kaya, K.-Gazel, M.-Çağlayan K.-Can Cengiz, F.-Sauvion, N. (2011): Survey on the presence of Cacopsylla pruni in Turkey: preliminary results. -Bulletin of Insectology; 64 (Supplement): S145-146

Tarcali, G.-Kiss, E.-Kövics, Gy.-Süle, S.-Irinyi, L.-Kiss, L. (2010): Kajszi ültetvények fitoplazmás pusztulása ('Ca. Phytoplasma prunorum') Borsod-Abaúj-Zemplén megyében. Agrártudományi Közlemények 2010/39: 34-41
Tibenszkyné Kiss, E. (2015): Eltérő virulenciájú fitoplazma törzsek kölcsönhatásának szerepe a keresztvédettség kialakulásában. Budapesti Corvinus Egyetem. Kertészettudományi Kar. Budapest, MTA ATK Növényvédelmi Intézet. 2015. (Doktori értekezés) $143 \mathrm{p}$.

Yvon, M.-Labonne, G.-Thebaud, G. (2004): Survival of European Stone Fruit Yellows phytoplasma outside fruit crop production areas: a case study in Southeastern France; Acta Horticulturae; 657: $477-481$ 